\title{
Protocol for chromosome-specific probe construction using PRINS, micromanipulation and DOP-PCR techniques
}

\author{
PAULO Z. PASSAMANI, CARLOS R. CARVALHO and FERNANDA A.F. SOARES
}

\begin{abstract}
Laboratório de Citogenética e Citometria, Departamento de Biologia Geral, Centro de Ciências Biológicas e da Saúde,
\end{abstract} Universidade Federal de Viçosa, Av. Peter Henry Rolfs, s/n, Campus Universitário, 36570-900 Viçosa, MG, Brazil

Manuscript received on February 15, 2016; accepted for publication on April 15, 2016

\begin{abstract}
Chromosome-specific probes have been widely used in molecular cytogenetics, being obtained with different methods. In this study, a reproducible protocol for construction of chromosome-specific probes is proposed which associates in situ amplification (PRINS), micromanipulation and degenerate oligonucleotide-primed PCR (DOP-PCR). Human lymphocyte cultures were used to obtain metaphases from male and female individuals. The chromosomes were amplified via PRINS, and subcentromeric fragments of the $\mathrm{X}$ chromosome were microdissected using microneedles coupled to a phase contrast microscope. The fragments were amplified by DOP-PCR and labeled with tetramethyl-rhodamine5-dUTP. The probes were used in fluorescent in situ hybridization (FISH) procedure to highlight these specific regions in the metaphases. The results show one fluorescent red spot in male and two in female $\mathrm{X}$ chromosomes and interphase nuclei.
\end{abstract}

Key words: DOP-PCR, FISH, micromanipulation, PRINS.

\section{INTRODUCTION}

Chromosome-specific probes have been widely used to identify chromosomes and elucidate complex ones (Gribble et al. 2004). These probes have been constructed by flow sorting of whole chromosomes or by microdissection, both involving a subsequent amplification (Thalhammer et al. 2004). However, in flow sorting several hundreds of chromosomes must be selected from suspensions to generate a painting probe (Telenius et al. 1992). Owing to this limitation, microdissection has become a popular method to

Correspondence to: Carlos Roberto Carvalho

E-mail: ccarvalh@ufv.br construct whole-chromosome and region-specific painting probes (Guan et al. 1994). Chromosome microdissection is accomplished by conventional or laser techniques. The conventional approach uses fine extended glass needles for collection of whole chromosomes or subchromosomal regions (Meltzer et al. 1992). In turn, laser microdissection employs a UV-laser microbeam in combination with laser-pressure catapulting (LPC) to isolate and eject the chromosome onto a collection device, speeding up the process (Schermelleh et al. 1999).

After microdissection, different strategies have been used to amplify the DNA sequence of the micromanipulated chromosome, such as 
degenerate oligonucleotide-primed PCR (DOPPCR) (Telenius et al. 1992), primer extension preamplification (PEP) (Zhang et al. 1992), linker adaptor-mediated PCR (LA-PCR) (Albani et al. 1993) or multiple displacement amplification (MDA) (Dean et al. 2002). DOP-PCR is the most commonly used technique, owing to its relative rapidity and efficiency. Besides, it can be used for amplification of any kind of chromosomes by means of degenerate primers, which randomly bind to the genome during the initial cycles of low stringency (Zhou and $\mathrm{Hu}$ 2007).

However, a limiting factor of these techniques is the need for a relatively large number of copies of the target. In order to decrease this number, Christian et al. (1999) performed a DOP-PCR in situ to increase the amount of DNA associated with the chromosome before the micromanipulation. Although this approach was potentially promising to capture a single chromosome, practically no other studies have been described using this strategy.

Therefore, considering the wide applicability of chromosome-specific probes, the present study aims to describe a modified version of the latter protocol that allows constructing a probe from a tiny region of human $\mathrm{X}$ chromosome by means of PRINS and DOP-PCR techniques.

\section{MATERIALS AND METHODS}

\section{LYMPHOCYTE CULTURE AND SLIDE} PREPARATION

Chromosomes were obtained via human lymphocyte culture initiated from blood of male and female volunteers. Blood collection and procedures for cytogenetic evaluation were performed in accordance with the safety standards and criteria of Ethics in Human Research, Resolution 196/96 of the National Health Council. Under laminar flow, 12 drops of blood were added to $5.0 \mathrm{~mL}$ of complete culture medium LymphoGrow ${ }^{\mathrm{TM}}\left(\right.$ Cytogen $\left.^{\circledR}\right)$ with the aid of a Pasteur pipette. The cultures were incubated at $37^{\circ} \mathrm{C}$ with $5 \% \mathrm{CO}_{2}$ (Sanyo ${ }^{\circledR} \mathrm{MCO}-$ 18AC model) for $72 \mathrm{~h}$. Next, $50 \mu \mathrm{L}$ of Colcemid ${ }^{\mathrm{TM}}$ $\left(\right.$ Sigma-Aldrich $\left.{ }^{\circledR}\right)$ were added and the cultures were incubated for $15 \mathrm{~min}$ at $37^{\circ} \mathrm{C}$. The cultures were then centrifuged, the supernatant discarded and the pellet resuspended in $0.075 \mathrm{M} \mathrm{KCl}$ solution $(\mathrm{pH}$ 6.8), preheated to $37^{\circ} \mathrm{C}$ for $30 \mathrm{~min}$ for hypotonic treatment. Fixation of the material was achieved in methanol: acetic acid $(3: 1)$ solution with five changes at $10 \mathrm{~min}$ intervals. The fixed material was stored in methanol. Slides were prepared by dripping and air-drying as described by Barch et al. (1997).

\section{In situ AMPLIFICATION}

For PRINS, slides containing male metaphases were prepared without the air-drying step and with subsequent washing with ultrapure water to remove the excess of fixative compounds. A final volume of $50 \mu \mathrm{L}$ of reaction mixture, constituted by 1 U Platinum ${ }^{\circledR}$ Taq DNA Polymerase High Fidelity (Invitrogen $^{\circledR}$ ), 1X enzyme-specific reaction buffer $\left(\right.$ Invitrogen $^{\circledR}$ ), $2 \mathrm{mM} \mathrm{MgSO}_{4}$ (Invitrogen $^{\circledR}$ ), 200 $\mathrm{mM}$ dNTP $\left(\right.$ Promega $^{\circledR}$ ) and $4 \mathrm{mM}$ DOP-primer (5'CCGACTCGAGNNNNNNATGTGG3' $\mathrm{ITD}^{\circledR}$ ), was carefully pipetted onto the slide. The slides were covered with plastic coverslip $(22 \times 60$ $\mathrm{mm})$, sealed with glue and placed in a Mastercycler ${ }^{\mathbb{R}}$ Gradient (Eppendorf ${ }^{\mathrm{TM}}$ ) thermocycler containing in situ adapter. The reaction conditions consisted of an initial denaturation step at $95^{\circ} \mathrm{C}$ for $10 \mathrm{~min}$, followed by 8 cycles at $94^{\circ} \mathrm{C}$ for $1 \mathrm{~min} ; 30^{\circ} \mathrm{C}$ for 5 min with a ramp rate of $0.3^{\circ} \mathrm{C} / \mathrm{s}$ to $68^{\circ} \mathrm{C}$ for $5 \mathrm{~min}$; 12 cycles at $94^{\circ} \mathrm{C}$ for $1 \mathrm{~min} ; 50^{\circ} \mathrm{C}$ for 5 min with a ramp rate of $0.3^{\circ} \mathrm{C} / \mathrm{s}$ to $56^{\circ} \mathrm{C}$ for $5 \mathrm{~min} ; 68^{\circ} \mathrm{C}$ for 5 $\mathrm{min}$; and final extension at $68^{\circ} \mathrm{C}$ for $5 \mathrm{~min}$.

\section{MICRODISSECTION}

After PRINS, the slides were rinsed in $2 \mathrm{X}$ SSC $0.1 \%$ Triton $\mathrm{X}-100$ solution and in ultrapure water. They were analyzed under microscope, and the 
metaphase images were digitized for identification of the $\mathrm{X}$ chromosomes before micromanipulation, since the banding procedure was not carried out in this methodology to prevent contamination. After careful identification of the $\mathrm{X}$ chromosomes, they were micromanipulated with the aid of glass needles (Femtotips ${ }^{\circledR}$-Eppendorf ${ }^{\mathrm{TM}}$ ) and a micromanipulator (TransferMan ${ }^{\circledR}$ NK 2 - Eppendorf ${ }^{\mathrm{TM}}$ ) coupled to an inverted phase contrast microscope IX70 (Olympus $^{\mathrm{TM}}$ ) mounted with lens LUCPlanFL N - UIS $260 \mathrm{X} / 0.70 \mathrm{Ph}$. Ten fragments of the $\mathrm{X}$ chromosomes were microdissected and placed into $0.2-\mathrm{mL}$ microtube containing $2 \mu \mathrm{L}$ of ultrapure water. The chromosomal fragments were treated with $0.5 \mathrm{mg} \cdot \mathrm{mL}^{-1}$ proteinase $\mathrm{K}$ at $37^{\circ} \mathrm{C}$ for $24 \mathrm{~h}$ for complete deproteinization of the chromatin, and the DNA was used as template for probe construction.

\section{TEMPLATE AMPLIFICATION AND LABELING}

The micromanipulated fragments were amplified by DOP-PCR with $15 \mu \mathrm{L}$ of reaction mixture containing $4 \mathrm{mM}$ DOP primer $\left(\right.$ ITD $\left.^{\circledR}\right), 200 \mathrm{mM}$ dNTPs (Promega ${ }^{\circledR}$ ), $2 \mathrm{mM} \mathrm{MgSO}_{4}$ (Invitrogen $^{\circledR}$ ), 1 U Platinum ${ }^{\circledR}$ Taq DNA Polymerase High Fidelity (Invitrogen ${ }^{\circledR}$ ) and 1X enzyme-specific buffer (Invitrogen ${ }^{\circledR}$ ) (adapted from Christian et al. 1999 and Hobza et al. 2004). Amplification was performed in a Mastercycler ${ }^{\circledR}$ Gradient (Eppendorf ${ }^{\mathrm{TM}}$ ) thermocycler under the following conditions: initial denaturation at $95^{\circ} \mathrm{C}$ for $10 \mathrm{~min}$, followed by 10 cycles at $94^{\circ} \mathrm{C}$ for $1 \mathrm{~min} ; 30^{\circ} \mathrm{C}$ for 2 min with a ramp rate of $0.3^{\circ} \mathrm{C} / \mathrm{s}$ to $68^{\circ} \mathrm{C}$ for $2 \mathrm{~min}$; 30 cycles at $94^{\circ} \mathrm{C}$ for $1 \mathrm{~min} ; 50^{\circ} \mathrm{C}$ for $2 \mathrm{~min}$ with a ramp rate of $0.3^{\circ} \mathrm{C} / \mathrm{s}$ to $56^{\circ} \mathrm{C}$ for $2 \mathrm{~min} ; 68^{\circ} \mathrm{C}$ for $2 \mathrm{~min}$; and final extension at $68^{\circ} \mathrm{C}$ for $5 \mathrm{~min}$. The reaction products were subjected to electrophoresis in $1.5 \%$ agarose gel to verify the quality of the amplified material, and quantitation was performed by spectrophotometry in Nanodrop ${ }^{\mathrm{TM}}$ device (Thermo Scientific ${ }^{\mathrm{TM}}$ ). The products obtained by DOP-PCR, which amplified fragments of 200 to
$600 \mathrm{bp}$ in satisfactory quantity, were selected for direct fluorescent labeling via another DOP-PCR reaction. For this, the following reaction mixture was used: $4 \mathrm{mM}$ DOP-primer $\left(\right.$ IDT $^{\mathbb{B}}$ ), $200 \mathrm{mM}$

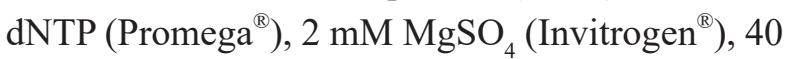
mM tetramethyl-rhodamine-5-dUTP $\left(\right.$ Roche $\left.^{\circledR}\right), 1 X$ enzyme-specific buffer $\left(\right.$ Invitrogen $\left.^{\circledR}\right)$, 1 U Platinum ${ }^{\circledR}$ Taq DNA Polymerase High Fidelity (Invitrogen ${ }^{\circledR}$ ), and $200 \mathrm{ng}$ of amplified DNA template to a final volume of $50 \mu \mathrm{L}$ for each reaction. The DOPPCR reaction was performed in a Mastercycler ${ }^{\circledR}$ Gradient (Eppendorf ${ }^{\mathrm{TM}}$ ) thermocycler under the following conditions: $95^{\circ} \mathrm{C}$ for $5 \mathrm{~min} ; 25$ cycles at $94^{\circ} \mathrm{C}$ for $1 \mathrm{~min} ; 30^{\circ} \mathrm{C}$ for $1 \mathrm{~min}$ with ramp rate of $0.3^{\circ} \mathrm{C} / \mathrm{s}$ to $68^{\circ} \mathrm{C}$ for $3 \mathrm{~min}$; and final extension at $68^{\circ} \mathrm{C}$ for $5 \mathrm{~min}$.

\section{FLUORESCENT in situ HYBRIDIZATION (FISH)}

For FISH, the slides containing metaphases obtained from cultured lymphocytes of male and female subjects were used, undergoing a series of pre-hybridization treatments. First, the slides were washed in phosphate buffered saline (PBS) for 5 min under agitation and subjected to ethanol series (70\%, 85\% and $100 \%$ for $5 \mathrm{~min}$ each). Next, they were treated with $0.4 \%$ RNAse $2 \mathrm{mg} . \mathrm{mL}-1$ diluted in $2 \mathrm{X} \mathrm{SSC}$ at $37^{\circ} \mathrm{C}$ for $1 \mathrm{~h}$ and rinsed in $2 \mathrm{X} \mathrm{SSC}$ (three times of $5 \mathrm{~min}$ ) and PBS (5 min). The slides were incubated in $0.005 \%$ pepsin diluted in 10 $\mathrm{mM} \mathrm{HCl}$ for $10 \mathrm{~min}$ at $37^{\circ} \mathrm{C}$, washed twice in PBS ( 2 min each time), post-fixed in fixative solution ( $2 \%$ formaldehyde, PBS, $50 \mathrm{mM} \mathrm{MgCl}_{2}$ ) for 10 min, washed twice in PBS (2 min each time) and subjected to cold ethanol series $(70 \%, 85 \%$ and $100 \%$ for $5 \mathrm{~min}$ each). Meanwhile, the probes were denatured for $10 \mathrm{~min}$ at $99^{\circ} \mathrm{C}$ in $35 \mu \mathrm{L}$ of a hybridization mixture containing $50 \%$ formamide, 2X SSC, $10 \%$ dextran sulfate, $1 \mu \mathrm{g}$ DNA competitor Human Cot-1 DNA (Invitrogen ${ }^{\circledR}$ ) and 200 ng of marked probe. The probes were immediately placed at $-20^{\circ} \mathrm{C}$, where they remained until the 
hybridization step. Subsequently, the previously denatured reaction mixture was applied to the slides, which were covered with plastic coverslip ( 22 x 40 $\mathrm{mm}$ ) and sealed with glue. The slides and the probe underwent a new simultaneous denaturation step at $75^{\circ} \mathrm{C}$ for $8 \mathrm{~min}$ and hybridization at $37^{\circ} \mathrm{C}$ for $20 \mathrm{~h}$ in a Thermobrite StatSpin ${ }^{\circledR}$ device $\left(\right.$ Abbott $\left.^{\circledR}\right)$. The coverslips were carefully removed and stringent washes were performed at $45^{\circ} \mathrm{C}$, consisting in three 5 -min washes in 50\% formamide and $2 \mathrm{X}$ $\mathrm{SSC}(\mathrm{pH} 7.0)$ followed by one wash $(5 \mathrm{~min})$ in $2 \mathrm{X}$ SSC and one wash (5 min) in $2 \mathrm{X}$ SSC $1 \%$ Triton $\mathrm{X}-100$. Subsequently, the slides were dehydrated in cold ethanol series $(70 \%, 85 \%$ and $100 \%$ for $5 \mathrm{~min}$ each), counterstained with $50 \mu \mathrm{L}$ of $5 \mathrm{mM}$ DAPI (4',6-diamidino-2-phenylindole) for $5 \mathrm{~min}$ and sealed with coverslips (24 x $50 \mathrm{~mm})$ in PBS solution.

\section{IMAGE CAPTURE}

The slides were analyzed using a BX60 fluorescence microscope (Olympus ${ }^{\mathrm{TM}}$ ) with filters WU (for DAPI) and WG (for rhodamine) and 100X immersion objective. The images were captured directly by a CCD video camera (Olympus DP71 ${ }^{\mathrm{TM}}$ ) coupled to a microscope and a computer containing a digitizer board and image analysis software.

\section{RESULTS}

The human lymphocyte culture conditions provided metaphases in sufficient number and exhibiting chromosomes morphologically suitable for PRINS, micromanipulation and FISH procedures. The metaphases showed well-spread chromosomes without overlaps, with preserved morphology and different levels of chromatin compaction that enabled distinguishing the homologous pairs. The prepared slides were subjected to PRINS and, after all treatments, the chromosome morphology remained suitable for micromanipulation. At this stage, a portion of the subcentromeric region of ten
X chromosomes was microdissected (Figure 1a, b). The fragments amplified by DOP-PCR generated amplification products ranging from 200 to 600 bp. Quantification of the material in Nanodrop ${ }^{\mathrm{TM}}$ spectrophotometer (Thermo Scientific ${ }^{\mathrm{TM}}$ ) revealed a DNA amount of $354.2 \mathrm{ng} . \mu \mathrm{L}^{-1}$, with $260 / 280$ ratio of 1.72 .

After hybridization, the subcentromeric region of a single $\mathrm{X}$ chromosome was marked in one chromosome of a male individual metaphase, showing a single corresponding fluorescent signal in interphase nuclei (Figure 1c, e, g). Hybridization in metaphases from a female individual revealed a pair of homologous $\mathrm{X}$ chromosomes marked in the subcentromeric region, showing two corresponding fluorescent red spots in interphase nuclei (Figure $1 \mathrm{~d}, \mathrm{f}, \mathrm{h})$. The chromosome labeling was effective in about $95 \%$ of the analyzed metaphases.

\section{DISCUSSION}

As the chromosomes were not stained, micromanipulation was carried out carefully to collect the same fragment with the same size. Staining was not performed to prevent loss of the fragments amplified by PRINS and to decrease the risk of contamination with exogenous DNA. However, some authors prefer using stained chromosomes to facilitate the identification process (Engelen et al. 1998, Weimer et al. 2001). Another positive aspect of the micromanipulation procedure was that the target chromosome fragments could be easily removed as a result of the rehydration step included before micromanipulation, as described by Engelen et al. (1998). This step was considered important because the fixation and dehydration procedures otherwise keep the chromosomes strongly adhered to the slide, making the capture more laborious (Bussey 1996).

The probe was constructed from only ten small micromanipulated fragments of $\mathrm{X}$ chromosomes after amplification by PRINS. Studies have reported 


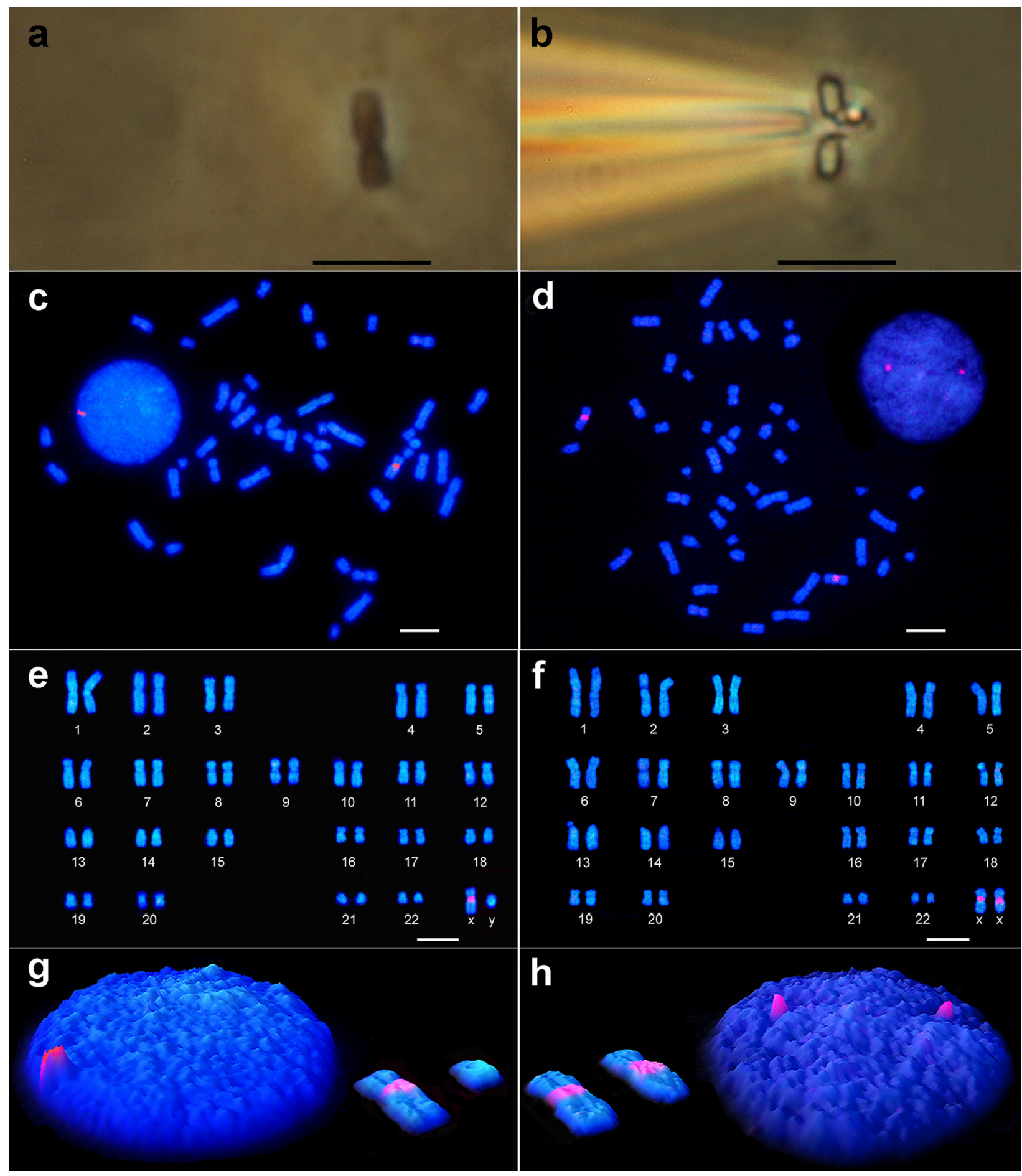

Figure 1 - Microdissection procedure and FISH using chromosome-specific probe obtained via DOP-PCR. Microdissection procedure (a) before and (b) after removal of the chromosome fragment. Probe hybridization in the X chromosome in metaphase of (c) male and (d) female individuals, counterstained with DAPI. Note the red fluorescent spots in the X chromosomes and nuclei. (e) Male and (f) female karyotypes showing the marks on the X chromosomes. (g, h) 3-D plots of the nuclei and sexual pair highlighting the positive signals. Bar $=10 \mu \mathrm{m}$. 
the need for large numbers of micromanipulated chromosomes to construct a probe (approximately 20). However, some authors have pointed out that the construction of probes with a lower number of chromosomes is possible (Guan et al. 1994, Engelen et al. 1998, Henning et al. 2008). Christian et al. (1999) described a protocol to generate probes from a single micromanipulated chromosome. As in the present study, these authors used PRINS as strategy to enhance the number of DNA sequence copies and to reduce the required amount of chromosomes to be micromanipulated. Nevertheless, their methodology did not provide repeatability, since no reports reproduced the procedure and not even the authors themselves continued this line of research.

The exposure of the micromanipulated chromosomal fragments to proteinase $\mathrm{K}$ is recommended for deproteinization of the chromatin (Weimer et al. 1999). In this study, adequate DNA for amplification was only obtained using proteinase $\mathrm{K}$ for $24 \mathrm{~h}$. However, some authors indicate other methods for digestion of proteins. Guan et al. (1994) used the topoisomerase I enzyme for treatment of the microdissected material. Differently, Engelen et al. (1998) performed a procedure employing the temperature as deproteinizing agent, subjecting the material to cycles of $30^{\circ} \mathrm{C}$ and $50^{\circ} \mathrm{C}$.

Amplification using DOP-PCR has been widely employed for probe construction (Christian et al. 1999, Zhou et al. 2001). Still, DOP-PCR conditions must be optimized beforehand to avoid preferential amplification and to generate fragments of 200 to $600 \mathrm{bp}$, a size range considered effective for probe construction (Hobza et al. 2004). In this sense, it is necessary to improve the time and temperature of annealing and extension for the enzymes. As the latter are highly processive at high temperatures, it is recommended to use the ramp rate between the annealing and extension temperatures (Henning et al. 2008). Another relevant factor in the amplification step is the primer concentration, as limiting primer levels may decrease the amplification rate in the last cycles of the PCR procedure (Czerny 1996). As suggested by Engelen et al. (1998), here we chose to use a higher primer concentration $(4 \mu \mathrm{M})$ to maintain the high amplification level.

We consider that the FISH procedure was efficient, marking only the chromosome corresponding to that which originated the probe in $95 \%$ of the metaphases, without nonspecific signals. Undesired hybridizations were suppressed by the addition of Cot-1, which competes for the repetitive regions of the probe (Craig et al. 1997).

In conclusion, a new methodology was standardized for efficient construction of a chromosome-specific probe using relatively small fragments and low number of DNA copies as template. The described protocol can be used to generate probes for screening of other chromosome regions and analyzing structural and numerical abnormalities. This methodology can be widely applied for many other organisms, not being restricted to human chromosomes.

\section{REFERENCES}

ALBANI D, CÔTÉ MJ, ARMSTRONG KC, CHEN Q, SEGAL A AND ROBERT LS. 1993. PCR amplification of microdissected wheat chromosome arms in simple "single tube" reaction. The Plant Journal 4(5): 899-903.

BARCH MJ, KNUTSEN T AND SPURBECK JL. 1997. The AGT cytogenetics laboratory manual, $3^{\text {rd }}$ ed., Philadelphia: Lippincott-Raven, 666 p.

BUSSEY KJ. 1996. Chromosome microdissection: on the cutting edge. Appl Cytogenet 22(2): 30-36.

CHRISTIAN AT, GARCIA HE AND TUCKER JD. 1999. PCR in situ followed by microdissection allows whole chromosome painting probes to be made from single microdissected chromosomes. Mamm Genome 10: 628631.

CRAIG JM, KRAUS J AND CREMER T. 1997. Removal of repetitive sequences from FISH probes using PCR-assisted affinity chromatography. Hum Genet 100: 472-476.

CZERNY T. 1996. High primer concentration improves PCR amplification from random pools. Nucleic Acids Res 24(5): 985-986. 
DEAN FB ET AL. 2002. Comprehensive human genome amplification using multiple displacement amplification. Proc Natl Acad Sci USA 99: 5261-5266.

ENGELEN JJM, ALBRECHTS JCM, HAMERS GJH AND GERAEDTS JPM. 1998. A simple and efficient method for microdissection and micro-FISH. J Med Genet 35: 265-268.

GRIBBLE S, BEE NL, PRIGMORE E, BURFORD DC AND CARTER NP. 2004. Chromo-some paints from single copies of chromosomes. Chromosome Res 12: 143-151.

GUAN XY, MELTZER PS AND TRENT JM. 1994. Rapid generation of whole chromosome painting probes (WCPs) by chromosome microdissection. Genomics 22: 101-107.

HENNING F, TRIFONOV V AND TOLEDO LFA. 2008. Use of chromosome microdissection in fish molecular cytogenetics. Gent Mol Biol 31(1): 279-283.

HOBZA R, LENGEROVA M, CERNOHORSKA H, RUBES J AND VYSKOT B. 2004. FAST-FISH with laser beam microdissected DOP-PCR probe distinguishes the sex chromosomes of Silene latifolia. Chromosome Res 12: 245-250.

MELTZER P, GUAN XY, BURGESS A AND TRENT JM. 1992. Rapid generation of region specific probes by chromosome microdissection and their application. Nature Genetics 1: 24-28.

SCHERMELLEH L, THALHAMMER S, HECKL W, PÖSL H, CREMER T, SCHÜTZE K AND CREMER M. 1999. Laser microdissection and laser pressure catapulting for the generation of chromosome-specific paint probes. BioTechniques 27: 362-367.

TELENIUS H, CARTER NP, BEBB CE, NORDENSKJOLD M, PONDER BA AND TUNNACLIFFE A. 1992.
Degenerate oligonucleotide-primed PCR: General amplification of target DNA by a single degenerate primer. Genomics 13: 718-725.

THALHAMMER S, LANGER S, SPEICHER MR, HECKL WM AND GEIGL JB. 2004. Generation of chromosome painting probes from single chromosomes by laser microdissection and linker-adaptor PCR. Chromosome Res 12: 337-343.

WEIMER J, KIECHLE M, SENGER G, WIEDEMANN U, OVENS-READER A, SCHUIERER E, KAUTZA M, SIEBERT R AND ARNOLD N. 1999. An easy and reliable procedure of microdissection technique for the analysis of chromosomal breakpoints and marker chromosomes. Chromosome Res 7: 355-362.

WEIMER J, KOEHLER MR, WIEDEMANN U, ATTERMEYER P, JACOBSEN A, KAROW D, KIECHER M, JONAT W AND ARNOLD N. 2001. Highly comprehensive karyotype analysis by a combination of spectral karyotyping (SKY), microdissection, and reverse painting (SKY-MD). Chromosome Res 9: 395-402.

ZHANG L, CUI X, SCHMITT K, HUBERT R, NAVIDI W AND ARNHEIM N. 1992. Whole genome amplification from single cell: Implications for genetics analysis. Prod Natl Acad Sci USA 89: 5847-5851.

ZHOU RN AND HU ZM. 2007. The development of chromosome microdissection and micro-cloning technique and its applications in genomic research. Cur Genomics 8: 67-72.

ZHOU Y, DANG B, WANG H, HU Z, WANG L AND CHEN Z. 2001. Microdissection of a single chromosome and construction of the microclone library from soybean. Euphytica 121: 129-135. 